\title{
Sacral Canal Myeloid Sarcoma as Initial Manifestation of Granulocytic Leukemia: MRI Features and Differential Diagnosis (with a Case Report)
}

\section{Granülositik Löseminin Başlangıç Bulgusu Olarak Sakral Kanal Myeloid Sarkomu: MRG Özellikleri ve Ayırıс Tanı (Olgu Sunumuyla)}

\author{
Xiao ANQI ${ }^{1}$, Huang SIQING ${ }^{1}$, Li ZHENLIN $^{2}$, You CHAO ${ }^{1}$ \\ ${ }^{1}$ Sichuan University, West China Hospital, Department of Neurosurgery, Chengdu, P. R. China \\ ${ }^{2}$ Sichuan University, West China Hospital, Department of Radiology, Chengdu, P. R. China
}

Corresponding Author: You CHAO / E-mail: youchaost@yahoo.cn

\begin{abstract}
Myeloid sarcoma initially occurring in the sacral canal is often misdiagnosed as other pathological tumors on MRI due to the lack of a definite history or clinical evidence of granulocytic leukemia. Here, we report a case of 24-year-old male patient with myeloid sarcoma misdiagnosed radiologically. On MRI, sacral myeloid sarcoma is characterized by homogeneous signal intensity, marked enhancement, and the lack of cystic degeneration, calcification and necrosis. Based on our study of this patient and review of the relevant literature, we believe that these MRI features in the sacral region may help us differentiate it from other pathological tumors, which could prompt further clinical examinations to confirm the diagnosis of granulocytic leukemia.
\end{abstract}

KEYWORDS: Myeloid sarcoma, Magnetic resonance imaging, Sacral canal

öz

Başlangıçta sakral kanalda oluşan myeloid sarkom sıklıkla kesin bir öykü veya granülositik lösemi için klinik bulgular olmaması nedeniyle MRG'de yanlışlıkla başka patolojik tümörler tanısı konur. Burada radyolojik olarak yanlış tanı konmuş myeloid sarkomlu 24 yaşında bir erkek hasta bildiriyoruz. MRG'de sakral myeloid sarkom homojen sinyal şiddeti, belirgin kontrast tutma ve kistik dejenerasyon, kalsifikasyon ve nekroz bulunmamasıyla karakterizedir. Bu hasta ve ilgili literatürü gözden geçirmemiz temelinde sakral bölgede bu MRG özelliklerinin bu lezyonu diğer patolojik tümörlerden ayırt etmemize yardımcı olacağını ve granülositik lösemi tanısını doğrulamak için başka klinik incelemelerin yapılmasını sağlayabileceğini düşünüyoruz.

ANAHTAR SÖZCÜKLER: Myeloid sarkom, Manyetik rezonans görüntüleme, Sakral kanal

\section{INTRODUCTION}

Myeloid sarcoma, also known as granulocytic sarcoma, is a manifestation of myelocytic leukemia with a predilection for the sacral canal. Its occurrence may precede the abnormalities of peripheral blood and bone marrow. Sacral myeloid sarcoma is often initially misdiagnosed as other pathological tumors due to lack of evidence of granulocytic leukemia, which will result in incorrect therapeutic schedule. So, understanding the characteristics of this disease on magnetic resonance imaging (MRI) may help us making differentiate diagnosis and proper treatment.

\section{CASE REPORT}

A 24-year-old male patient, with an 8-month history of claudication, right lower limb numbness, mild urinary frequency and incontinence was admitted to our hospital.
Lumbar and sacral MRI showed a soft-tissue mass in the vertebral canal at the L5-S5 level involving the epidural and subdural space, occupying the entire sacral canal, and infiltrating and compressing the adjacent vertebral bodies into an arc shape with irregular borders and loss of bone cortex. The right L5-S1 intervertebral foramen and bilateral sacral foramens were invaded and expanded. The lesion spread from inside the vertebral canal to the lateral, front and back of L5 and sacral vertebrae through the L5-S1 intervertebral foramen and sacral foramina, surrounding the spine and invading vertebral cortex. The mass was iso/ hypointense on $\mathrm{T} 1 \mathrm{WI}$, iso/hyper-intense on $\mathrm{T} 2 \mathrm{WI}$, and showed homogeneous enhancement on postcontrast T1WI. No visible peripheral capsule, central necrosis or calcification were seen. Inside the sacral vertebrae, there were irregular patchy lesions that were hypointense on $\mathrm{T} 1 \mathrm{Wl}$, hyperintense on $\mathrm{T} 2 \mathrm{WI}$ and 

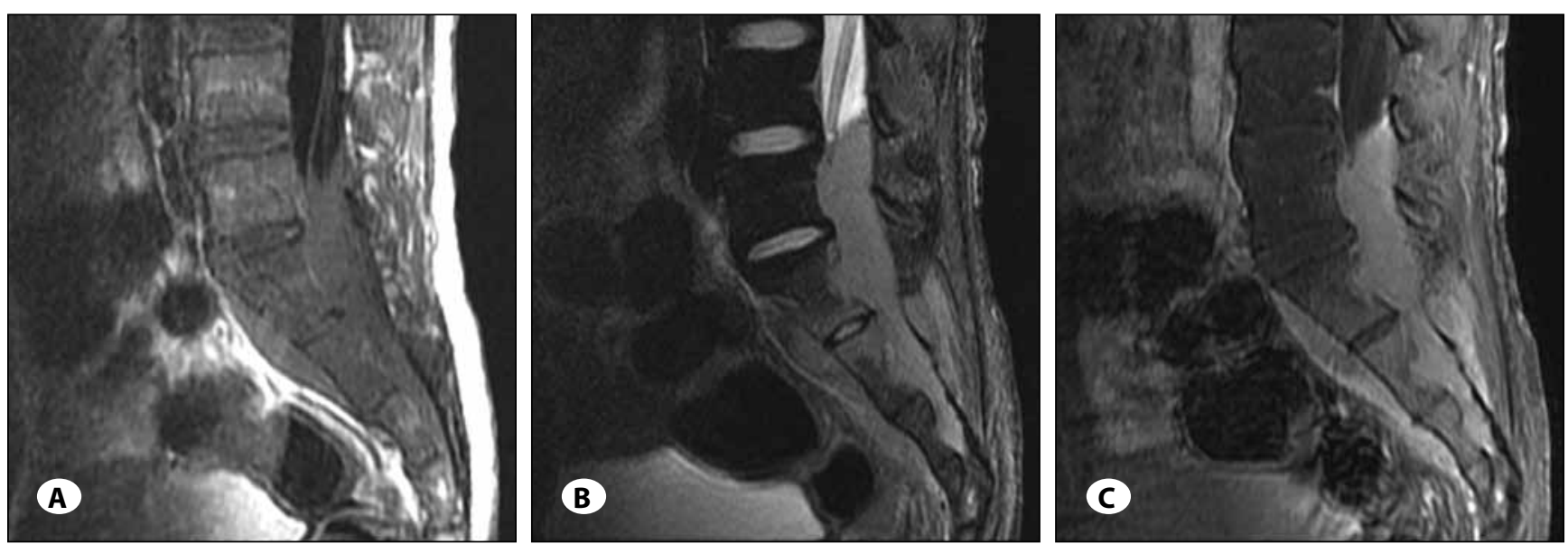

Figure 1: MRI of lumbar and sacral myeloid sarcoma. A mass with iso-/hypointensity on T1WI (A) and iso-/hyperintensity on fatsuppression T2WI (B) occupied the vertebral canal at the L5-S5 level, with the adjacent vertebral bodies infiltrated and compressed into an arc shape. Inside the sacral vertebrae, there were irregular patchy lesions with long $\mathrm{T} 1$ and long $\mathrm{T} 2$ signals. While on postcontrast T1WI (C), the mass was homogeneously enhanced, and the involved S1-5 vertebrae with partial loss of bone cortex showed prominent enhancement.

showed prominent enhancement on postcontrast images (Figure 1A-C). A chordoma was considered the most probable diagnosis by radiologists. Preoperative routine blood test showed normal white blood cell, red blood cell and platelet counts, and biochemical parameters were within normal ranges. Decompressive semi-laminectomy with intraspinal tumor excision at L5-S5 was performed at our neurosurgery department. As was intraoperatively noted, there was a solid mass without capsule in the L5-S5 spinal canal, invading both epidural and subdural spaces, spreading into paravertebral regions, and clearly adhering to the adjacent tissues, with the right L5-S1 paraspinal muscles stiffened. The mass was carefully peeled and partially resected. Postoperative pathological examination confirmed the lesion as myeloid sarcoma. Immunohistochemistry: Tumor cell MPO (++), CD34 $(+)$, CD43 (+), TDT (-), CD20 (-), CD3 (-), CD30 (-), bcl (-), CD10 (-), muml (-), desmin (-), myogenin (-), NSE (-), CD99 (+), and Ki67: $50 \%$. The patient's symptoms were alleviated after the surgery. Postoperative bone marrow puncture indicated M2 subtype of acute myelocytic leukemia (AML) with $60 \%$ myeloblasts. Chemotherapy with daunomycin was administered. Subsequent bone marrow examination indicated $\mathrm{AML}$ remission. The patient is currently in consolidation therapy.

\section{DISCUSSION}

Myeloid sarcoma is a local neoplasm consisting of immature myeloblasts, which often occurs secondary to AML, with an incidence of $2.5-9.1 \%$ myelogenous leukemia, and more commonly in the AML-M2 subtype (1,3,4). Myeloid sarcoma might precede abnormalities of bone marrow and peripheral blood, and can be detected by CT or MRI as a solitary mass. It may also be initially noted as a solitary mass on imaging in patients whose peripheral blood and bone marrow are abnormal (5). Either way, misinterpretation of its image is frequent, as in the case we reported above. Although the AML of our patient was confirmed by postoperative bone marrow puncture, it could not be ascertained whether the bone marrow was normal or not when the sacral mass was detected by MRI. Nevertheless, there is no doubt that myeloid sarcoma in the patient was found as the initial clinical manifestation of the lesion. Lumbar and sacral vertebrae and canals are prone to a variety of pathological tumors, such as chordoma, neurofibroma, schwannoma, and metastatic tumor. Thus, a solitary myeloid sarcoma initially presenting at this site tends to be misdiagnosed on imaging when a definite history of leukemia is absent (2). By understanding the imaging characteristics of myeloid sarcoma, and differentiating it from other pathological tumors in terms of location, texture, signal, border, enhancement appearance, and adjacent bone change, we may increase its detection, propose diagnostic possibilities of leukemia and myeloid sarcoma, further perform a relevant examination to make the proper diagnosis, and make correct therapeutic decisions.

Sacral canal myeloid sarcoma may invade both epidurally and subdurally when the mass is sufficiently large. As an infiltrating malignancy, myeloid sarcoma is typically without a capsule. The shape of the tumor is mostly irregular, and there is no fine-line capsule shadow between the normal tissues and lesion. In most cases, spinal myeloid sarcoma has a homogeneous texture, which returns a uniform signal as iso/hypo-intensity on $\mathrm{T} 1 \mathrm{WI}$, iso/ hyper-intensity on $\mathrm{T} 2 \mathrm{WI}$, and markedly homogeneous enhancement on postcontrast T1WI. These MRI manifestations reflect that myeloid sarcoma is characterized by scanty calcification, rare cystic change and necrosis pathologically, which are distinctly different from chordoma and schwannoma. When the tumor is larger, occupying the vertebral canal and invading paravertebral space through the intervertebral foramens and sacral foramens, it often enlarges the spinal canal, intervertebral and sacral foramens, also causes resorption of the sacral 
border cortex. When the adjacent vertebrae are infiltrated by the tumor tissue, the patch lesions in the vertebrae can be found with long T1 and long T2 signal intensity and the same prominent enhancement as an intraspinal mass. On fatsuppression $\mathrm{T} 2 \mathrm{Wl}$, these lesions can be shown more clearly. These MRI manifestations of the lesion, which suggest a probable diagnosis of myeloid sarcoma, are demonstrated in our case.

Myeloid sarcoma of sacral canal is often misdiagnosed as chordoma, neurofibroma or schwannoma, malignant fibrous histiocytoma, or metastasis. Although the site is the same, their MRI manifestations are different from that of myeloid sarcoma, and understanding this is crucial for clinicians in the differential diagnosis. Chordoma occurs in the residual notochordal tissues from human embryo with a predilection for the skull base and sacral vertebrae. Sacral chordoma is manifested as osteolytic and expansive destruction in the central site of sacral vertebrae. Although the lesion may also occupy the sacral canal and paravertebral region, it often has prominent calcification or necrosis, resulting in heterogeneous signals on $\mathrm{T} 1 \mathrm{WI}$ and $\mathrm{T} 2 \mathrm{Wl}$, which is evidently different from the homogeneous signal of myeloid sarcoma, and also different from the signal and morphological changes in sacral vertebrae infiltrated by myeloid sarcoma. As for sacral neurofibroma or schwannoma, the range of involvement may be similar to myeloid sarcoma when it invades vertebral canal and paravertebral space. However, either one is mostly encapsulated with a clear border, which is hypointense on $\mathrm{T} 1 \mathrm{WI}$ and $\mathrm{T} 2 \mathrm{WI}$ on MRI, and appears heterogeneous or as a circular enhancement on postcontrast T1Wl. These imaging features are particularly common in schwannoma, suggesting the pathological changes of calcification, cystic degeneration and necrosis of the tumor, which is unlike myeloid sarcoma with the homogeneous parenchyma, lack of a capsule, calcification and cystic change. As a benign tumor, schwannoma mainly causes compressive bone resorption to adjacent sacrum and expansion of sacral canal and foramens, where in most cases the signal of sacrum is normal, that is distinctive from the signal changes due to infiltration of myeloid sarcoma. Pathologically, hemorrhage, necrosis, cystic change and calcification are often seen in malignant fibrous histiocytoma of sacrum, and cause mixed signal intensity on MRI compared with myeloid sarcoma. Sacral osteolytic metastatic tumor is often characterized as irregular intravertebral destruction and results in vertebral collapse, cortex disappearance, and a soft tissue mass with inhomogeneous signal intensity. These are different from the MRI manifestations of infiltration of bone marrow in leukemia. Sometimes, it can be difficult to differentiate metastases from myeloid sarcoma simply based on the evidence on imaging.
Definite primary tumor history and presence of multiple lesions at other sites have confirmatory value for diagnosis of metastases.

Regarding our case with AML that initially manifested as myeloid sarcoma, we summarize the main potential reasons for misinterpretation on MRI as follows: 1) Sacral canal myeloid sarcoma is rare, and tends to be overlooked by radiologists on establishing diagnosis; 2) Neurosurgeons overlooked the possibility of leukemia due to lack of clinical evidence of leukemic bone marrow and peripheral blood abnormalities, and absence of leukemia history; and 3) the clinicians and radiologists lack sufficient understanding of the imaging manifestations of myeloid sarcoma.

\section{CONCLUSION}

On MRI, myeloid sarcoma appears as soft-tissue mass with homogeneous signal intensity, marked enhancement and absence of cystic change, calcification and necrosis These MR manifestations features are different from those of chordoma, neurofibroma or schwannoma, and malignant fibrous histiocytoma. When the imaging features above are present in sacral region without a definite leukemia history, myeloid sarcoma could be strongly suggested. If defused infiltration signal of bone marrow is accompanied simultaneously, the possibility of myeloid sarcoma with leukemia might be considered. Clinicians should be alerted for timely bone marrow and peripheral blood examinations to prevent incorrect or missed diagnosis. The differential diagnosis of myeloid sarcoma on MRI has significant clinical value for early accurate diagnosis, timely radiotherapy or adjuvant chemotherapy, avoidance of ineffective or unnecessary surgery, reduction of the neurological sequelae, improvement of living quality and survival rate.

\section{REFERENCES}

1. Antic D, Verstovsek S, Elezovic I, Grujicic D, Gotic M, Bila J, Perunicic M, Jakovic L: Spinal epidural granulocytic sarcoma in non-leukemic patient. Int J Hematol 89(1):95-97, 2009

2. Balleari E, Panarello S, Capello E, Grosso M, Passalia C, Pitto P, Raggi F, Roccatagliata L, Cabiddu F and Ghio R: Granulocytic sarcoma: An unusual cause of spinal cord compression. Int J Clin Oncol 12(3):234-237,2007

3. Graham A, Hodgson T, Jacubowski J, Norfolk D, Smith C: MRI of perineural extramedullary granulocytic sarcoma. Neuroradiology 43:492-495,2001

4. Seok JH, Park J, Kim SK, Choi JE, Kim C: Granulocytic sarcoma of the spine: MRI and clinical review. AJR 194:485-489,2010

5. Serefhanoglu S, Goker H, Aksu S, Buyukasik Y, Sayinalp N, Haznedaroglu IC, Ozcebe OI: Spinal myeloid sarcoma in two non-leukemic patients. Inter Med 49:2493-2497,2010 